\title{
Identification and Characterization of Cell Wall Proteins of a Toxic Dinoflagellate Alexandrium catenella Using 2-D DIGE and MALDI TOF-TOF Mass Spectrometry
}

\author{
Da-Zhi Wang, Hong-Po Dong, Cheng Li, Zhang-Xian Xie, Lin Lin, and Hua-Sheng Hong \\ State Key Laboratory of Marine Environmental Science, Environmental Science Research Centre, Xiamen University, \\ Xiamen 361005, China \\ Correspondence should be addressed to Da-Zhi Wang, dzwang@xmu.edu.cn
}

Received 20 January 2011; Accepted 30 June 2011

Copyright $\odot 2011$ Da-Zhi Wang et al. This is an open access article distributed under the Creative Commons Attribution License, which permits unrestricted use, distribution, and reproduction in any medium, provided the original work is properly cited.

The cell wall is an important subcellular component of dinoflagellate cells with regard to various aspects of cell surface-associated ecophysiology, but the full range of cell wall proteins (CWPs) and their functions remain to be elucidated. This study identified and characterized CWPs of a toxic dinoflagellate, Alexandrium catenella, using a combination of 2D fluorescence difference gel electrophoresis (DIGE) and MALDI TOF-TOF mass spectrometry approaches. Using sequential extraction and temperature shock methods, sequentially extracted CWPs and protoplast proteins, respectively, were separated from A. catenella. From the comparison between sequentially extracted CWPs labeled with Cy3 and protoplast proteins labeled with Cy5, 120 CWPs were confidently identified in the 2D DIGE gel. These proteins gave positive identification of protein orthologues in the protein database using de novo sequence analysis and homology-based search. The majority of the prominent CWPs identified were hypothetical or putative proteins with unknown function or no annotation, while cell wall modification enzymes, cell wall structural proteins, transporter/binding proteins, and signaling and defense proteins were tentatively identified in agreement with the expected role of the extracellular matrix in cell physiology. This work represents the first attempt to investigate dinoflagellate CWPs and provides a potential tool for future comprehensive characterization of dinoflagellate CWPs and elucidation of their physiological functions.

\section{Introduction}

The dinoflagellates are a diverse group of unicellular algae that comprise a large part of the marine phytoplankton [1]. They are not only important primary producers and an important part of the food chain in the marine ecosystem, but also the major causative species of harmful algal blooms (HABs) in the coastal zone [2]. Moreover, many dinoflagellate species can produce various potent toxins that impact human health through the consumption of contaminated shellfish, coral reef fish, and finfish or through water or aerosol exposure [3]. In the past few decades, much effort has been devoted to the study of HABs and dinoflagellate toxins. However, many aspects of them are still not well elucidated due to the unusual physiological and molecular features of dinoflagellates, and this has impeded our understanding of dinoflagellate-caused HABs and subsequently their monitoring, mitigation, and prevention [4].
Dinoflagellates typically have an outer covering called the theca or amphiesma (Figure 1), which consists of a continuous outermost membrane, an outer plate membrane, and a single-membrane bounded thecal vesicle $[5,6]$. Inside this vesicle, a number of cellulosic thecal plates are subtended by a pellicular layer. Thecal plates usually consist primarily of cellulose and polysaccharides with a small amount of proteins. Although much effort has been devoted to understanding the cell wall ultrastructure of dinoflagellates using electron microscopic and cytochemical approaches, molecular information on cell wall biogenesis and dynamics is lacking.

It is known that a number of proteins and enzymes reside on the cell wall and outer membrane of phytoplankton, such as high-affinity binding proteins $[7,8]$, transporters [9-14], stress proteins [15], signaling proteins [16], and ectoenzymes [17-25]. These proteins play important roles ranging from nutrient utilization, defense, signaling, and cell adhesion 


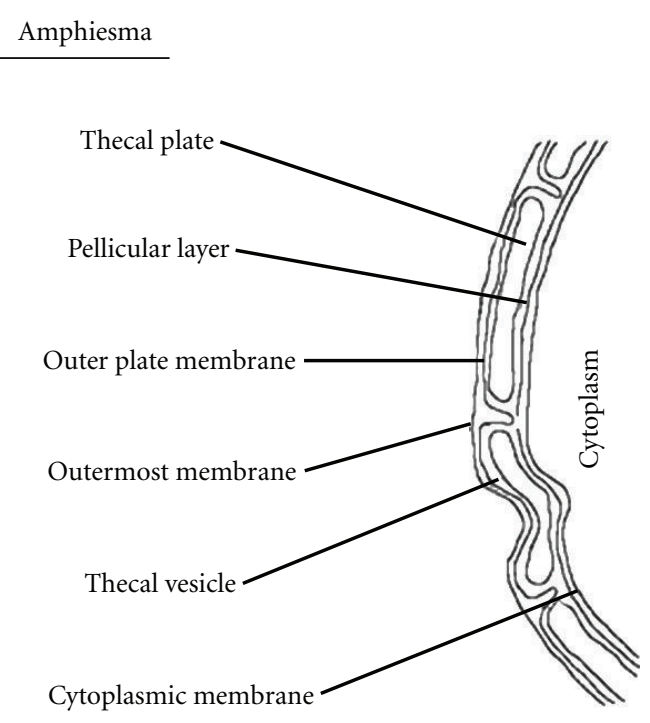

(a)

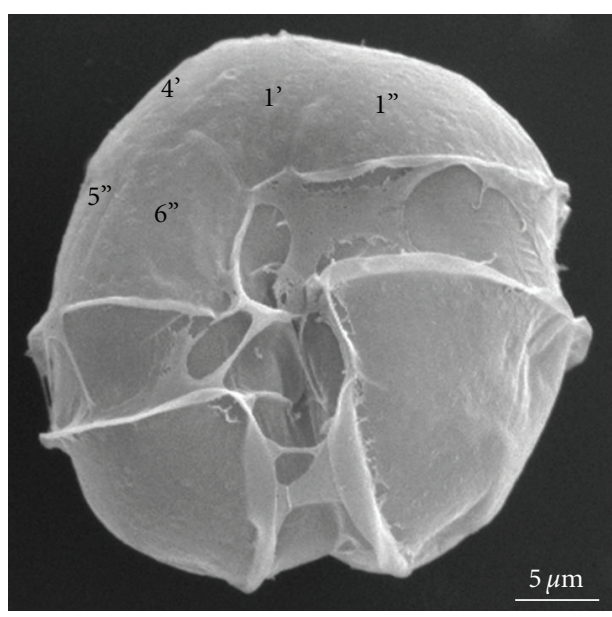

(b)

FIgURE 1: Schematic diagram of the amphiesma of a typical thecate dinoflagellate based on Morrill and Loeblich (1984). (a) Structure of the amphiesma, including a continuous outermost membrane, an outer plate membrane, a single-membrane bounded thecal vesicle, and a cytoplasmic membrane. Inside this vesicle, a number of cellulosic thecal plates are subtended by a pellicular layer. (b) Scanning electron micrograph of A. catenella, with the continuous outermost membrane obvious on the cell surface.

to cell-cell recognition. The cell wall of dinoflagellates is a subcellular component of substantial interest with regard to various aspects of cell surface associated ecophysiology. However, there are few experimental data available for the cell wall of dinoflagellates compared with other organisms due to the lack of the whole genome. So far, only a limited number of cell wall proteins (CWPs) and enzymes have been identified and characterized at the biochemical and functional level, and neither the mechanism of their functions nor their locations have been elucidated [2630]. A few studies indicate that cell wall-associated proteins and their activities are known to be induced or increased by factors limiting the growth of these members of the eukaryotic phytoplankton, because they may enhance cell scavenging of nutrients. Moreover, dinoflagellate CWPs may also be involved in signaling pathways [16]. Clearly, the cell wall presents an important site of interaction between algal cells and their environment. In light of this, a better understanding of dinoflagellate CWPs composition may help to reveal various physiological activities on the cell wall as well as in the blooming mechanism of dinoflagellates.

Study of CWPs has often relied on the methods used for their isolation from the cell wall of dinoflagellates. However, at present, there is no ideal method for the isolation of CWPs although many studies have been devoted to various membrane proteins. One of the current strategies is to extract CWPs from whole cells using a sequential extraction method [31-33]. However, this approach causes the cells to break during the long chemical extraction, and this results in potential cross-contamination of the CWPs [32]. Specific labeling methods, for example, biotinylation or the use of the radioisotope Na125I, are also developed to recognize and isolate the cell surface proteins (CSPs) from dinoflagellates
$[26,30]$. However, these methods led to a loss of solubility of the proteins due to the multiple additions of large hydrophobic groups, and, moreover, these methods only address CSPs and not the CWPs.

Global techniques such as proteomics provide effective strategies and tools for profiling and identifying proteins of dinoflagellates [34-38]. In contrast to conventional biochemical approaches that address one or a few specific proteins at a time, proteomic techniques allow simultaneous isolation and identification of hundreds to thousands of proteins in one sample. Fluorescence difference gel electrophoresis (DIGE) technology is a newly developed 2D gelbased approach that employs three fluorescent succinimidyl esters, termed CyDyes, to differentially label proteins prior to electrophoretic separation [39]. Because of the sensitivity and extended linear dynamic range of these dyes, this technique facilitates not only quantification over a comparatively wide dynamic range with high accuracy, but also enables relative quantification with reference to an internal standard, thereby also facilitating the analysis of an adequate set of biological replicates in order to obtain the most significant data on protein regulation. This technique is recently applied for identifying biomarkers, designing novel drug targets, and monitoring therapeutic processes [40-43].

In this study, we present a newly developed method for the identification and characterization of CWPs from A. catenella DH01, an HAB-causing dinoflagellate species widely spread in the coastal waters of China[44]. By comparing sequentially extracted CWPs labeled with Cy3 and protoplast proteins labeled with Cy5, 120 CWPs were confidently identified on the 2D DIGE gel, and the majority gave positive identification of protein orthologues in the protein database by de novo sequence analysis and database 
searching (MS-BLAST). The goal of this study was to establish an efficient and reliable method to identify CWPs from dinoflagellates and to characterize putative proteins in order to provide a foundation for future investigation of the functions and expression of CWPs in A. catenella as well as other dinoflagellates.

\section{Materials and Methods}

2.1. Organism and Culture Conditions. A. catenella DH01 was provided by the Culture Collection Center of Marine Bacteria and Algae of the State Key Laboratory of Marine Environmental Science, Xiamen University, China. A unialgal isolate was routinely maintained in K medium [45] at $20^{\circ} \mathrm{C}$ under a $10: 14 \mathrm{~h}$ light: dark photoperiod at a light intensity of approximately $100 \mu \mathrm{mol}$ photons $\mathrm{m}^{-2} \mathrm{~s}^{-1}$ provided using fluorescent lamps. The cells for the experiments were grown in $5,000 \mathrm{~mL}$ flasks containing $4,000 \mathrm{~mL}$ of $\mathrm{K}$ medium, and the culture conditions were the same as above. The $\mathrm{K}$ medium did not contain any protein. Approximately $2 \times 10^{7}$ cells of $A$. catenella in their exponential growth phase were collected with centrifugation at $3,000 \times \mathrm{g}$ for 30 minutes at $4^{\circ} \mathrm{C}$. The cell pellets were rinsed twice with precooled sterilized seawater to avoid any carryover of culture medium and extracellular proteins and were used for the extraction of CWPs and protoplast proteins.

2.2. Preparation of Sequentially Extracted CWPs. For CWP extraction, the cell pellets were sequentially extracted with $0.2 \mathrm{M} \mathrm{CaCl}_{2}, 50 \mathrm{mM}$ CDTA in $50 \mathrm{mM}$ sodium acetate $(\mathrm{pH}$ 6.5), $2 \mathrm{mM} \mathrm{DTT}$, and $1 \mathrm{M} \mathrm{NaCl}$ at $4^{\circ} \mathrm{C}$ for $30 \mathrm{~min}$ each, and finally to $0.2 \mathrm{M}$ borate ( $\mathrm{pH} 7.5)$ at room temperature for $30 \mathrm{~min}$, with gentle vortexing. The extracts were pooled together and precipitated with three volumes of ice-cold $20 \%$ TCA $(\mathrm{v} / \mathrm{v})$ in acetone overnight at $-20^{\circ} \mathrm{C}$ and centrifuged at $20,000 \mathrm{~g}$ for $30 \mathrm{~min}$ at $4^{\circ} \mathrm{C}$ (Hettich ROTINA 38R Refrigerated Centrifuges, Germany). The supernatant was discarded, and the precipitate was washed twice with ice-cold $90 \%$ acetone $(\mathrm{v} / \mathrm{v})$ containing $20 \mathrm{mM}$ DTT and then twice with ice-cold $100 \%$ acetone. The protein obtained was air-dried to remove residual acetone and subsequently dissolved in $50 \mu \mathrm{L}$ rehydration buffer ( $\mathrm{pH}$ 8.5) containing $7 \mathrm{M}$ urea, $2 \mathrm{M}$ thiourea, $4 \%$ CHAPS (w/v), and $30 \mathrm{mM}$ Tris and then stored at $-80^{\circ} \mathrm{C}$ for proteomic analysis. This protein sample was termed sequentially extracted CWPs.

2.3. Preparation of Protoplast Proteins. $1 \times 10^{7}$ cells were resuspended in sterilized sea water and maintained at $4^{\circ} \mathrm{C}$ for one and a half hours then at $20^{\circ} \mathrm{C}$ for $10 \mathrm{~min}$. After this treatment, the cell walls became detached from the protoplasts without the cell being broken (Figure 2). The suspension was centrifuged at $4,000 \mathrm{~g}$ for $30 \mathrm{~min}$ at $4^{\circ} \mathrm{C}$. After removing the supernatant, the pellet was separated into two layers, cell walls in the upper layer and protoplasts in the lower layer (Figure 2(e)). The cell wall layer was introduced to a membrane filter of $5 \mu \mathrm{M}$ diameter pore size (Whatman) with a pipette and gently washed three times with sterilized sea water to avoid contamination by extracellular proteins. The protoplasts were removed on a $10 \mu \mathrm{M}$ diameter pore size filter (Whatman) and washed three times with sterilized sea water to avoid contamination by the cell walls. $1 \mathrm{~mL}$ Trizol reagent was added to the protoplast pellet collected using centrifugation, and it was subjected to sonication on ice. Subsequently, $200 \mu \mathrm{L}$ of chloroform was added to the cell lysate before shaking it vigorously for $15 \mathrm{~s}$. The mixture was allowed to stand for $5 \mathrm{~min}$ at room temperature before being centrifuged at $12000 \times \mathrm{g}$ for $15 \mathrm{~min}$ at $4^{\circ} \mathrm{C}$. The top pale-yellow or colorless layer was removed, and $300 \mu \mathrm{L}$ of ethanol was added to resuspend the reddish bottom layer and this mixture centrifuged at $2000 \times$ g for 5 min at $4{ }^{\circ} \mathrm{C}$. The supernatant was transferred to a new tube and $1.5 \mathrm{~mL}$ of isopropanol was added. The mixture was allowed to stand for at least $20 \mathrm{~min}$ for precipitation of proteins at room temperature. It was then centrifuged at $14000 \times \mathrm{g}$ for $10 \mathrm{~min}$ at $4^{\circ} \mathrm{C}$, and the pellet obtained was briefly washed with $95 \%$ ethanol before being allowed to air dry. $500 \mu \mathrm{L}$ of rehydration buffer with $7 \mathrm{M}$ urea, $2 \mathrm{M}$ thiourea and $4 \% \mathrm{~W} / \mathrm{V}$ CHAPS was added to solubilize the protein pellet before loading onto the first dimension isoelectric focusing (IEF).

2.4. Minimal Labeling of Proteins Using Fluorescent Dye. Sequentially extracted CWPs and protoplast proteins were subjected to minimal labeling using the fluorescent dyes $\mathrm{Cy} 3$ and $\mathrm{Cy} 5$ according to the manufacturer's instructions. Aliquots of $50 \mu \mathrm{g}$ of each sample were separately labeled. Briefly, stock cyanine dyes $(14 \mathrm{nmol} / \mu \mathrm{L})$ were diluted in freshly prepared DMF to $400 \mathrm{pmol} / \mu \mathrm{L}$ and $8 \mathrm{pmol}$ dye was added per $1 \mu \mathrm{g}$ of protein in the cell lysate. The sample was vortexed, briefly centrifuged, and left on ice for $30 \mathrm{~min}$ in the dark. No primary amines, DTT, or carrier ampholytes were included in the lysis buffer as such components could potentially react with the $N$-hydroxy succinimide ester group of the cyanine dyes. The labeling reaction was quenched by adding $1 \mu \mathrm{L}$ of $10 \mathrm{mML}$-lysine per $400 \mathrm{pmol}$ of dye. The sequentially extracted CWPs and protoplast proteins were labeled with Cy3and Cy5, respectively. Thereafter, the Cy3and Cy5-labeled samples were mixed at a ratio of $1: 1$ (equating to $100 \mu \mathrm{g}$ of total protein) and prepared for IEF.

2.5. Two-Dimensional Gel Electrophoresis. For 2D DIGE, the labeling protein samples were mixed with a rehydration buffer ( $7 \mathrm{M}$ urea, $2 \mathrm{M}$ thiourea, $4 \% \mathrm{w} / \mathrm{v}$ CHAPS, $1 \%$ DTT, and $0.5 \% \mathrm{v} / \mathrm{v}$ IPG) before loading onto IPG strips with a linear $\mathrm{pH}$ gradient from 4-7 (Immobiline Drystrip, GE Healthcare Life Science, Piscataway, US). The sample was subjected to IEF using an IPGphor III system with $24 \mathrm{~cm}$ IPG strips and the following protocol: $6 \mathrm{~h}$ at $40 \mathrm{~V}$ (active rehydration), $6 \mathrm{~h}$ at $100 \mathrm{~V}, 0.5 \mathrm{~h}$ at $500 \mathrm{~V}, 1 \mathrm{~h}$ at $1000 \mathrm{~V}, 1 \mathrm{~h}$ at $2000 \mathrm{~V}, 1.5 \mathrm{~h}$ at $10000 \mathrm{~V}$, and $6 \mathrm{~h}$ at $10000 \mathrm{~V}$ for $60000 \mathrm{Vh}$. The minimal Vh applied was 60000 units. Subsequently, the immobilized $\mathrm{pH}$ gradient strips were equilibrated for $15 \mathrm{~min}$ in reducing buffer containing $6 \mathrm{M}$ urea, $2 \%$ SDS, $50 \mathrm{mM}$ Tris-Cl (pH 8.8), 30\% glycerol, and 1\% DTT, followed by equilibration for $15 \mathrm{~min}$ in alkylation buffer containing $6 \mathrm{M}$ urea, 2\% SDS, $50 \mathrm{mM}$ Tris- $\mathrm{Cl}$ ( $\mathrm{pH} 8.8$ ), 30\% glycerol, and 2.5\% iodoacetamide. Second-dimension SDS-PAGE gels $(12.5 \%)$ were run on a GE Ettan DALT six at $0.5 \mathrm{w} / \mathrm{gel}$ for $1 \mathrm{~h}$ and then at $17 \mathrm{w} / \mathrm{gel}$ for $6 \mathrm{~h}$. 


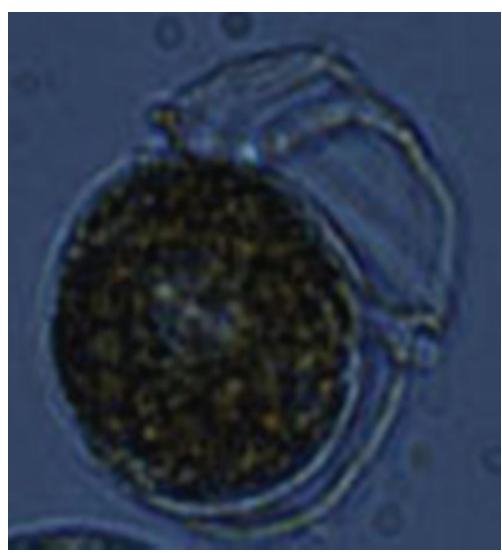

(a)

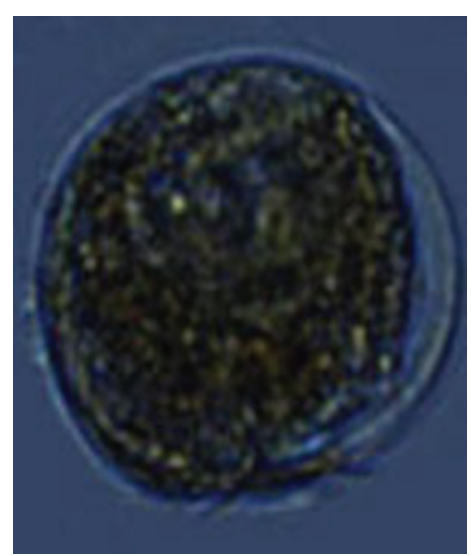

(b)

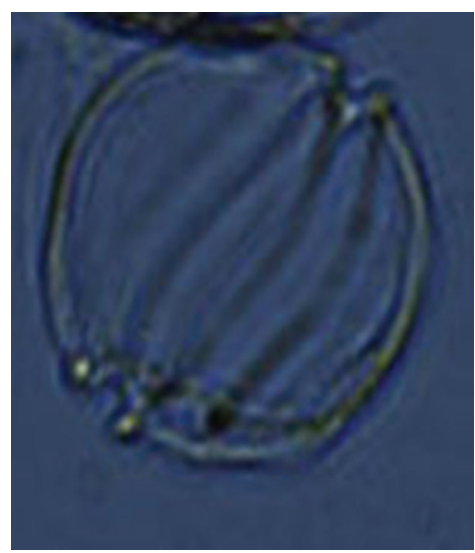

(c)

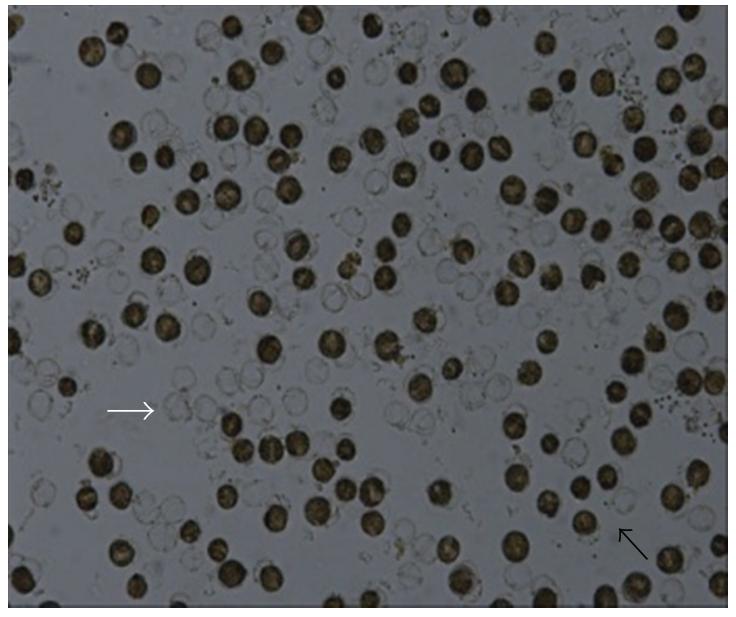

(d)

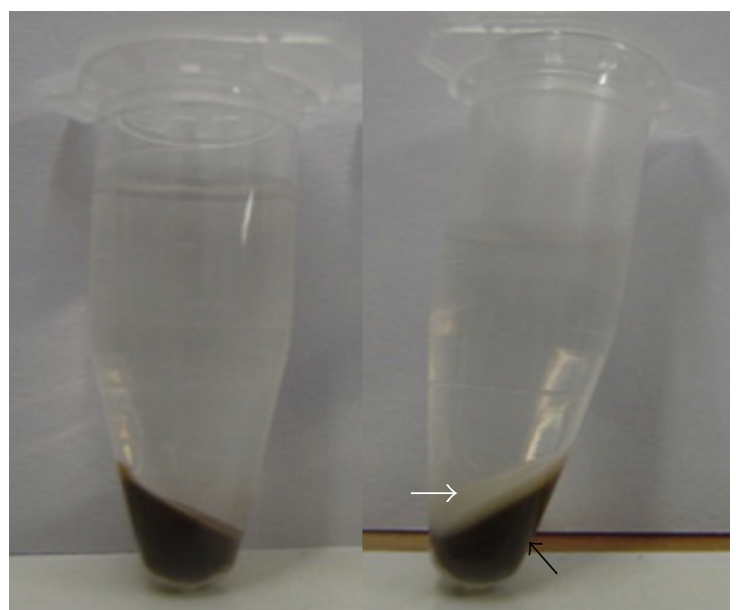

(e)

Figure 2: Preparation of protoplasts of A. catenella DH01 using the temperature shock method. (a), (b), and (c) are photographs of the intact cell, the protoplast and the cell wall of A. catenella DH01 under the light microscope. (d) A mixture of cell walls (white arrow) and protoplasts (black arrow). (e) Concentrated cell walls (white arrow) and protoplasts (black arrow). (The magnitude was $10 \times 20$ ).

2.6. Gel Scanning, Digitizing, and Data Analysis. The resultant analytical gels were scanned using a Typhoon 9400 scanner (Amersham 4 Biosciences/GE Healthcare). The specific excitation and emission wavelengths for each of the fluorescent dyes were recommended by the manufacturer. Gel images were scanned at a resolution of $100 \mu \mathrm{m}$ and preprocessed using ImageQuant software (version 5.2, Amersham Biosciences/GE Healthcare). Cropped gel images were analyzed using DeCyder 2D software (version 6.5, Amersham Biosciences/GE Healthcare). The differential in-gel analysis (DIA) algorithm detected overlapping spots on a combined image derived from merging individual images from the two samples tagged by $\mathrm{Cy} 3$ and Cy5. Protein spots which were identified as CWPs between the sequentially extracted CWPs and protoplast proteins were marked for spot excision and subsequent protein identification using MALDI TOF-TOF.

2.7. In-Gel Digestion. 120 CWPs identified using 2D DIGE were manually excised from the prepared silver stained 2-DE gels (Figure 4), and the silver-stained gel pieces were rinsed once with MilliQ water and destained in $100 \mathrm{mM}$ sodium thiosulfate and $30 \mathrm{mM}$ potassium ferricyanide until the gel pieces became white. They were then rinsed three times in Milli-Q water, shrunk with $100 \%$ acetonitrile for $15 \mathrm{~min}$, and air-dried at room temperature for $30 \mathrm{~min}$. All gel pieces were incubated with $12.5 \mathrm{ng} / \mu \mathrm{L}$ sequencing grade trypsin (Roche Molecular Biochemicals) in $20 \mathrm{mM} \mathrm{NH} \mathrm{HCO}_{3}$ overnight at $37^{\circ} \mathrm{C}$. After digestion, $1 \mu \mathrm{L}$ of supernatant was pipetted and spotted on the target plate then air-dried at room temperature. $1 \mu \mathrm{L}$ of matrix (4-hydroxy-cyanocinnamic acid in $30 \%$ CAN, $0.1 \%$ TFA) was laid over the samples on the target plate until they dried completely.

2.8. Mass Spectrometric Analysis. MALDI-TOF mass spectrometry and tandem TOF/TOF mass spectrometry were carried out with a 4800 Plus MALDI TOF-TOF Analyzer (Applied Biosystems, Foster City, USA) equipped with a neodymium: yttrium-aluminum-garnet laser. The laser wavelength and the repetition rate were $355 \mathrm{~nm}$ and $200 \mathrm{~Hz}$. The MS spectra were processed using the Peak Explorer (Applied Biosystems) software allowing nonredundant and fully automated selection of precursors for tandem mass 


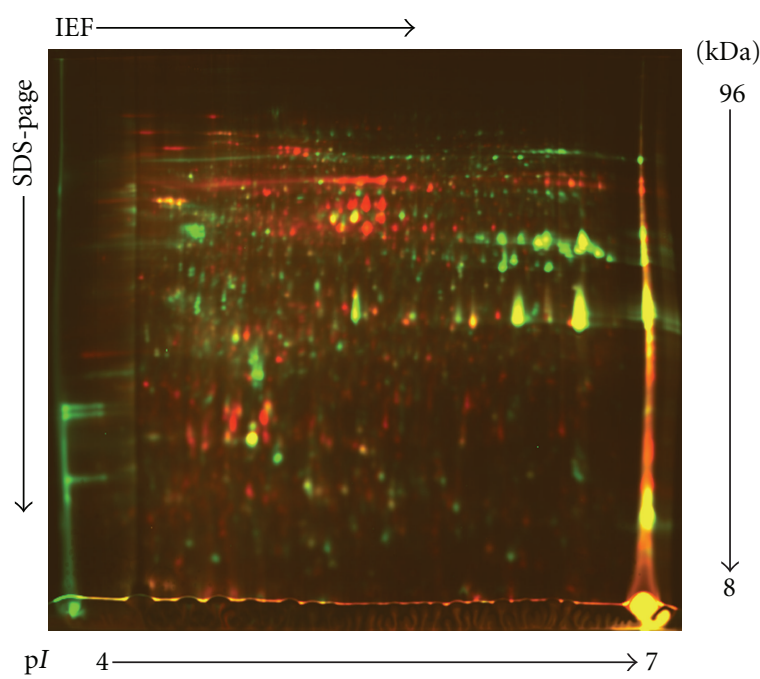

Figure 3: 2D DIGE analysis of sequentially extracted CWPs and protoplast proteins labeled using the fluorescent dyes Cy3 (green) and Cy5 (red), respectively. This representative 2D DIGE image for protein expression maps used a $12.5 \%$ homogenous SDS-PAGE gel in the $\mathrm{pH}$ range 4 to 7 .

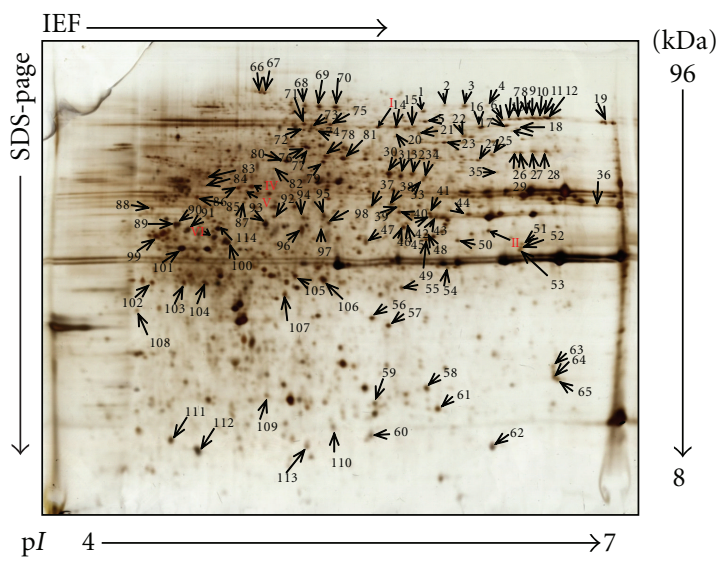

Figure 4: Representative 2-DE gel of CWPs from an A. catenella DH01 sample stained with silver. The proteins were resolved in 4-7 linear $\mathrm{pH}$ gradient (Immobiline DryStrips; $240 \times 3 \times 0.5$ ) and $12.5 \%$ SDS-PAGE $(2400 \times 2000 \times 1 \mathrm{~mm})$. 120 CWPs were separated and identified (indicated by arrows) from A. catenella DH01.

spectrometry (MS/MS) acquisition. At least 2000 laser shots were typically accumulated in the MS mode, whereas in the MS/MS mode spectra from up to 5000 laser shots were acquired and averaged. The peak detection criteria used were a minimum $\mathrm{S} / \mathrm{N}$ of 10 , a local noise window width mass/charge $(\mathrm{m} / \mathrm{z})$ of 250 and a minimum full-width halfmaximum (bins) of 2.9. The mass spectra were internally calibrated using porcine trypsin autolytic products $(\mathrm{m} / \mathrm{z}$ $842.51,1045.564$, and $2211.104 \mathrm{Da}$ ) resulting in mass errors of less than $30 \mathrm{ppm}$. A maximum of the five strongest precursor ions per protein spot were chosen for MS/MS analysis. The following monoisotopic precursor selection criteria were used for MS/MS: minimum S/N filter of 50 , excluding the most commonly observed peptide peaks for trypsin and keratin, and excluding the precursors within 200 resolution. In the TOF1 stage, all ions were accelerated to $1 \mathrm{kV}$ under conditions promoting metastable fragmentation. The peak detection criteria used were an $\mathrm{S} / \mathrm{N}$ of 10 and a local noise window width of $250(\mathrm{~m} / \mathrm{z})$.

2.9. Database Search. A combined MS and MS/MS search was first performed against the NCBI nonredundant database with no taxonomic restriction using an in-house MASCOT server (Version 2.2). The raw MS and MS/MS spectra were processed using GPS Explorer software (Version 3.5, Applied Biosystems). For protein spots with a scores confidence interval below 95\%, their MS/MS spectra were used for automated de novo sequencing using the Applied Biosystems DeNovo Explorer software [46]. Briefly, each MS/MS spectrum produced ten peptide sequence candidates, and each peptide sequence had a score associated with it that indicated how much of the total ion abundance in the MS/MS spectrum was accounted for by the typical fragment ions that could be calculated for the particular sequence. The closer to 100 was the score, the greater the likelihood that all or most of the sequence generated by DeNovo Explorer was correct.

De novo generated peptide sequences were performed for similarity searches using the MS-BLAST algorithms [46]. The MS-BLAST searches were conducted at the Heidelberg server (http://dove.embl-heidelberg.de/Blast2/msblast.html) against the NCBI nonredundant database using standard settings with no taxonomic restriction. All sequences obtained from an MS/MS spectrum were spaced with the minus symbol (-) and were merged into a single string, and submitted to an MS BLAST search as reported above. The MS-BLAST search results were considered significant if the resulting scores were higher than the threshold score indicated in the MS-BLAST scoring scheme.

\section{Results}

3.1. Identification of CWPS Using 2D DIGE. In this study, two protein fractions were obtained from A. catenella: one fraction was sequentially extracted CWPs prepared using a sequential chemical extraction method, a traditional plant CWP preparation method; the other was protoplast proteins prepared using a temperature shock method. The former was labeled with Cy3 and the latter with Cy5, and then, they were pooled together to run 2D DIGE. An overview of the fluorescent DIGE images of the sequentially extracted CWPs and protoplast proteins of A. catenella, and the overlaying of these two images are shown in Figure 3. The differentially expressed proteins were evaluated using DeCyder 2D software. This software identifies protein spots and compares the spot intensities for up to three samples run simultaneously on a single 2-DE gel. Figure 3 shows qualitative comparisons of sequentially extracted CWPs and protoplast proteins run on a single gel. Overlaying the images allowed direct comparison of the two. Green spots were sequentially extracted CWPs; red spots were protoplast proteins; yellow spots were the same proteins presented in 
both sequentially extracted CWPs and protoplast proteins. Using DIA software analysis, 120 candidate protein spots were identified as CWPs (green spots) in the CyDye staining gel, and the majority of these CWPs was separated in the apparent molecular mass range of $14-50 \mathrm{kDa}$, and they had $\mathrm{p} I$ ranges of 4.0-7.0.

3.2. Categorization of the A. catenella CWPs. To further characterize the samples, 120 confidently identified CWPs of A. catenella DH01 were excised from the silver-staining gels (Figure 4) and trypsinized, before subjection to MALDITOF-TOF MS analysis. By searching against the NCBI nonredundant database using the MASCOT algorithm, no CWPs could be identified which were able to meet statistical significance. This is not surprising, however, since no dinoflagellate genome has been established at present. Furthermore, de novo sequencing and MS-BLAST similarity searches were used for protein identification. A total of 42 proteins were identified, most of which were associated with cell wall modifying enzymes, cell wall structure, transport/binding, signaling, and defense (Table 1). Among them, 15 proteins were putative cell wall-modifying enzymes, including four hydrolases, two dehydratases, two dehydrogenases, four oxidoreductases, two acyltransferases, and one protease. These proteins are involved in various physiological processes on the cell wall during cell growth and development. Three putative proteins, D-alanyl-Dalanine ligase A, UDP-glucose 4-epimerase and penicillinbinding protein (PBP) were possibly involved in cell wall construction. Transport/binding proteins, and lipoprotein represented another major group of proteins present in the cell wall. Of these, three belonged to ATP-binding cassette (ABC) family, three were other types of transport/binding proteins, and the other was lipoprotein. These proteins were involved in transporting various substrates across the cell wall membranes. The signaling proteins were another important component in CWPs of A. catenella, four of them were receptors, one was a binding protein, and two were other signal proteins. Five proteins related to cell defense were identified, they were polymorphic membrane protein B/C family (PMP), dihydropteroate synthase (DHPS), Vpu protein, FmtA-like protein, and SPAC328.04 protein.

In addition to the above proteins, several other proteins such as At2g46420/F11C10.11, CG2962, hypothetical membrane protein, and PB407L were also characterized amongst the CWPs of A. catenella, which reflects the roles of CWPs in cell surface physiology and in interactions between cell and environment.

\section{Discussion}

4.1. Isolation and Identification of CWPs. In this study, we prepared CWPs using a sequential extraction method. The cells were extracted first with $\mathrm{CaCl}_{2}$, then sequentially with CDTA, DTT, borate, and $\mathrm{NaCl}$, which can efficiently extract weak bound, strongly ionically bound, and pectinbound proteins as well as glycoproteins. This method was successfully used to extract CWPs from suspension-cultured cells of plant species and did not cause contamination of the proteins [31]. However, we found that the extracts became red during the extraction process and a few broken cells were also observed under the microscope (data not shown), indicating that cytosolic proteins might have been released during extraction and so contaminated the CWPs. Continuous extraction with chemical regents might also increase the permeability of the cell wall (theca) membrane and protoplast membrane which would have led to the leakage of intracellular proteins and subsequently contamination of the CWPs. A study on cell wall proteomics of a green alga, Haematococcus pluvialis, demonstrates that the sequential extraction method results in contamination of CWPs with intracellular proteins [32]. Several intracellular proteins, RuBisco small subunit orthologue, and ATP synthase-chain orthologue were found in the SDS-PAGE of the CWPs, although the contamination was relatively minor. Thus, the sequential extraction method is not a reliable approach for the extraction of CWPs for a cell wall proteomic study of dinoflagellates, and so, our study used the 2D DIGE method to identify CWPs by combining the sequential extraction method with the protoplast preparation method. The sequentially extracted CWPs were labeled by Cy3, while the protoplast proteins were labeled by Cy5. By comparing the differential expressed proteins to exclude overlayed proteins run on a single gel, the contamination of the intracellular proteins resulting from broken cells was excluded, and the CWPs were confidently identified. This approach provided a reliable and efficient tool to prepare and identify the CWPs of dinoflagellates.

4.2. Functions of CWPs in A. catenella. In this study, 42 proteins associated with cell wall-modifying enzymes, cell wall structure, transport/binding, signaling, and defense were tentatively identified from A. catenella using de novo sequencing and MS-BLAST similarity searches. These proteins reflected their roles in cell wall physiology.

It is known that several reactions (hydrolysis, transglycosylation, transacylation, and redox reactions) are catalyzed by cell wall-modifying enzymes $[47,48]$. In our study, 15 putative cell wall-modifying enzymes were identified from the A. catenella cell wall, including hydrolases, dehydratases, dehydrogenases, oxidoreductases, acyltransferases, and protease. Hydrolases are classified as EC 3 in the EC number classification of enzymes and catalyze the hydrolysis of various chemical bonds, for example, carbon-nitrogen, ester, and peptide. Various hydrolases are reported in bacteria and higher plant cell walls and play important roles in fruit ripening and tissue softening of plants as well as bacterial germination, vegetative growth, and sporulation $[49,50]$. However, little information is available concerning dinoflagellates. In our study, four hydrolases, the carbon-nitrogen family, competence protein comA, $\mathrm{BH} 3453$ protein, and probable transmembrane protein, were identified from A. catenella cell walls. Two of them are involved in breaking carbonnitrogen bonds and appear to be involved in the reduction of organic nitrogen compounds and ammonia production. Aside from these hydrolase proteins, a protease, methionine aminopeptidase (MAP), was identified from the cell wall. MAP is responsible for the removal of the amino-terminal 
TABLE 1: Functional categorization of CWPs from A. catenella DH01.

\begin{tabular}{|c|c|c|c|}
\hline Spot no. & Accession no. & Identification of MS-blast & MS-blast score (HSPs) \\
\hline \multicolumn{4}{|c|}{ Cell wall modifying enzymes } \\
\hline III & AACY01006738 & Quinoprotein ethanol dehydrogenase & $114(2)$ \\
\hline $\mathrm{V}$ & Q7S9I3 & Acyl-CoA dehydrogenase & $107(2)$ \\
\hline 5 & Q9F1X6 & Phosphotransacetylase & $100(2)$ \\
\hline 8 & Q8XTK4 & Probable transmembrane protein & $135(3)$ \\
\hline 24 & Q5WKD5 & Mannonate dehydratase & $104(2)$ \\
\hline 27 & Q635P5 & Hydrolase, carbon-nitrogen family & $59(1)$ \\
\hline 37 & Q7NLM8 & Gll1094 protein & $65(1)$ \\
\hline 43 & Q88D51 & 5,10 -methylenetetrahydrofolate reductase & $80(1)$ \\
\hline 46 & D00131 & Tyrosinase & $73(1)$ \\
\hline 66 & СР000025 & 8-amino-7-oxononanoate synthase & $64(1)$ \\
\hline 69 & P51973 & Competence protein comA & $65(1)$ \\
\hline 80 & Q63QT9 & Gamma-glutamyl phosphate reductase & $107(2)$ \\
\hline 81 & Q5UU97 & Enolase & $141(3)$ \\
\hline 98 & Q9K7B3 & BH3453 protein & $102(2)$ \\
\hline 102 & Q72CF9 & Methionine aminopeptidase & $64(1)$ \\
\hline \multicolumn{4}{|c|}{ Transport/binding proteins and lipoproteins } \\
\hline I & Q39909 & Luciferin-binding protein & $110(2)$ \\
\hline 17 & O73697 & Calcium channel alpha-1 subunit homolog & $75(1)$ \\
\hline 36 & Q6FPN9 & $\begin{array}{l}\text { Similar to uniprot|P40548 Saccharomyces } \\
\text { cerevisiae YIL016w SNL1 }\end{array}$ & $76(1)$ \\
\hline 85 & Q926C3 & $\begin{array}{c}\text { Outer membrane lipoprotein omp16 } \\
\text { homolog }\end{array}$ & $97(2)$ \\
\hline 97 & СР000009 & Carbamoyl-phosphate synthase large chain & $70(1)$ \\
\hline 100 & Q833S0 & $\mathrm{ABC}$ transporter, ATP-binding protein & $97(2)$ \\
\hline 112 & Q6IV89 & F1Fo-ATPase synthase f subunit & $59(1)$ \\
\hline \multicolumn{4}{|c|}{ Signaling proteins } \\
\hline II & Q01369 & $\begin{array}{l}\text { Guanine nucleotide-binding protein beta } \\
\text { subunit-like protein }\end{array}$ & $152(3)$ \\
\hline 18 & Q7T0K6 & Melanocortin 4 receptor & $64(1)$ \\
\hline 25 & CAAJ01000020 & Cg1 protein, putative & $70(1)$ \\
\hline 57 & Q6WQQ4 & Translocon-associated protein beta & $67(1)$ \\
\hline 72 & AE006464 & possible G-protein receptor & $99(2)$ \\
\hline 88 & Q9VQM8 & CG34393 & $68(1)$ \\
\hline 103 & Q98TY6 & Tyrosine kinase negative regulator $\mathrm{Cbl}$ & $137(3)$ \\
\hline \multicolumn{4}{|c|}{ Cell wall structure-related proteins } \\
\hline VI & Q8H6H9 & Cell division inhibitor MinD & $66(1)$ \\
\hline 1 & Q6N415 & Putative D-alanyl-D-alanine ligase A & $105(2)$ \\
\hline 99 & Q82D96 & Putative UDP-glucose 4-epimerase & $64(1)$ \\
\hline 111 & C2Q9T5 & Penicillin-binding protein & $66(1)$ \\
\hline \multicolumn{4}{|c|}{ Defense } \\
\hline IV & AE002181 & polymorphic membrane protein $\mathrm{B} / \mathrm{C}$ family & $67(1)$ \\
\hline 31 & Q9WXP7 & Dihydropteroate synthase & $101(2)$ \\
\hline 63 & Q9Q6Y7 & Vpu protein & $65(1)$ \\
\hline 74 & Q8TR39 & FmtA-like protein & $70(1)$ \\
\hline 109 & Q9P3U2 & SPAC328.04 protein & $60(1)$ \\
\hline \multicolumn{4}{|c|}{ Uncharacterized proteins } \\
\hline 32 & Q9SKD8 & At2g46420/F11C10.11 & $106(2)$ \\
\hline 49 & Q9W2X5 & CG2962 & $60(1)$ \\
\hline 15 & Q89W76 & hypothetical membrane protein & $73(1)$ \\
\hline 78 & Q65173 & PB407L & $104(2)$ \\
\hline
\end{tabular}


(initiator) methionine from nascent eukaryotic cytosolic and cytoplasmic prokaryotic proteins if the penultimate amino acid is small and uncharged. The occurrence of protease in cell walls is reported in bacteria, green algae, and higher plants. In a green alga, $H$. pluvialis, six putative proteases are identified and are postulated to be involved in processing and/or turnover of CWPs during cell growth and development [32].

Two dehydratases, mannonate dehydratase and enolase, were identified from the A. catenella cell wall. Mannonate dehydratase belongs to the family of lyases, specifically the hydrolases, which cleave carbon-oxygen bonds and participate in pentose and glucuronate interconversions. Enolase, also known as phosphopyruvate dehydratase, is a metalloenzyme responsible for the catalysis of 2-phosphoglycerate to phosphoenolpyruvate, the ninth and penultimate step of glycolysis. The two enzymes may exert a role in energy provision for cell wall formation.

A number of oxidoreductases were identified amongst the CWPs of A. catenella, including Gll1094 protein, 5, 10-methylenetetrahydrofolate reductase, tyrosinase, and gamma-glutamyl phosphate reductase. Aside from these proteins, two dehydrogenases (ethanol dehydrogenase and acyl-CoA dehydrogenase) were also detected in A. catenella. Acyl-CoA dehydrogenase catalyzes the initial step in each cycle of fatty acid $\beta$-oxidation and results in the introduction of a trans double bond between C2 and C3 of the acylCoA thioester substrate. Recently, several oxidoreductases, such as peroxidase, peptide $\mathrm{Met}(\mathrm{O})$ reductase 3, cytokinin oxidase, thioredoxin H-type 5, and UDP-Nacetylmuramatedehydrogenase, are identified in $H$. pluvialis cell wall extract [32]. It is suggested that oxidoreductases might cause reduction of cell wall extensibility by forming bridges across phenolic residues and adjacent CWPs or polysaccharides [51].

Two acyltransferases, phosphotransacetylase and 8amino-7-oxononanoate synthase, were found in A. catenella. These two enzymes belong to the family of transferases, specifically the acyltransferase transferring groups rather than the aminoacyl groups. The former participates in taurine and hypotaurine metabolism, pyruvate metabolism, and propanoate metabolism, while the latter participates in biotin metabolism. Both of them might play important roles in the formation and stability maintenance of the cell wall.

Three putative proteins identified in this study were possibly involved in cell wall construction. PBP is the primary enzyme involved in cell wall biosynthesis including muramoylpentapeptide carboxypeptidase, peptide syntheses, transpeptidases, and hexosyltransferases. In bacteria, $\mathrm{PBP}$ is involved in the final stage of the synthesis of peptidoglycan, the major component of bacterial cell walls. Occurrence of the three proteins suggested that the cell wall of dinoflagellates may contain components similar to bacterial peptidoglycan, which can form a strong and rigid lattice-like structure. Recently, three proteins associated with cell wall construction, S-layer protein, cellulose synthase, and 1UDP$\mathrm{N}$-acetylmuramoyl-alanine-D-glutamateligas, were identified from a green alga $H$. pluvialis [32]. Moreover, cell division inhibitor MinD, a peripheral protein, was identified in our study. MinD is a ubiquitous ATPase that plays a crucial role in the selection of the division site in eubacteria, chloroplasts, and probably Archaea and cooperates with MinC to form a division inhibitor at the cell division site that is topologically regulated by MinE. Recently, MinD has been found in four green algae, and the overexpression of MinD results in the MinCD complex binding all cell division sites and inhibiting cell division and leads to a long and nonseptate filamentous cell [52]. Moreover, MinD affects the diameters of cells. Since in dinoflagellates with a theca (amphiesma) little is known about the cell wall biogenesis and dynamics, identification of MinD suggested that this protein might act as a mediator to regulate cell wall growth and cell size when exposed to environmental stresses.

Seven putative transport/binding proteins and lipoprotein represented another major group of proteins present in the cell wall of $A$. catenella. ABC family proteins are transmembrane proteins that utilize the energy of ATP hydrolysis to carry out various biological processes including translocation of various substrates across membranes, and nontransport-related processes such as translation of RNA and DNA repair. They transport a wide variety of substrates across extra- and intracellular membranes, including metabolic products, lipids and sterols, and drugs. Recently, six ATP-binding cassette transporters are identified in the cell wall of $H$. pluvialis [32]. In Synechocystis, ABC-type transporters represent the most abundant transporters in the periplasmic space that are involved in the uptake of inorganic nutrients [33]. These studies indicate that ATPbinding cassette transporters might play important roles in the nutrient transport of dinoflagellates. Aside from these proteins, outer membrane lipoprotein OMP 16, similar to uniprot P40548 and calcium channel alpha-1 subunit homolog, were also identified in the CWPs of A. catenella, and these proteins played important roles in protein binding, lipid anchor, and calcium binding of the cell walls. Interestingly, luciferin-binding protein, a protein involved in the bioluminescence reaction, was identified from the CWPs of A. catenella. It is interesting to note that most of the proteins described above were previously found to be associated with the plasma membrane. This suggests that potential direct physical connections may occur between the plasma membrane and the cell wall and/or interactions at the plasma-cell wall interface [53].

The signaling proteins are another important component in plant cell walls, which regulate various biological processes occurring in the cell wall, such as signal transduction, cell shape and size regulation, stress response, and defense. Melanocortin 4 receptor and G-protein receptor are two transmembrane receptors that sense molecules outside the cell and activate inside signal transduction pathways and, ultimately, cellular responses. G protein-coupled receptors are found only in eukaryotes. Translocon-associated protein beta and tyrosine kinase negative regulator $\mathrm{Cb} 1$ are a signal sequence receptor and a cell surface receptor linked to signal transduction, respectively. Guanine nucleotide-binding proteins are glycoproteins anchored on the cytoplasmic cell membrane. They are mediators for many cellular processes, including signal transduction, protein transport, growth regulation, and polypeptide chain elongation. They are also 
known as GTP-binding proteins and GTPases. Almost all members of this super family of proteins act as a molecular switch, which is on when GTP is bound and off when GDP is bound. CG34393 was involved in regulation of small GTPase-mediated signal transduction. Our study also found one light signal transduction protein, Cg1 protein, which is a light induced protein and regarded as a possible member of a light signal transduction chain in parsley [54], indicating that $\mathrm{Cg} 1$ protein might function as a light-driven proton pump and take advantage of light energy directly as proteorhodopsin in A. catenella.

Proteins related to cell defense were also identified in cell wall of A. catenella. PMP is a bacterial outer membrane protein which might play important roles in the growth and development of Chlamydia pneumoniae [55]. DHPS, which has been found in bacteria, is a key enzyme in producing dihydropteroate. In the lower eukaryote Pneumocystis carinii, DHPS is the C-terminal domain of a multifunctional folate synthesis enzyme [56]. Finding DHPS in A. catenella suggested that this protein might have originated from the symbiotic bacteria which are hosted on the surface of $A$. catenella cells. Vpu protein and FmtA-like protein are two important proteins which play important roles in resisting bacteria and viruses.

4.3. Protein Identification Using De Novo Analysis and Database Searching. De novo analysis coupled with database searching is regarded as a powerful proteomic technique for protein identification, particularly for species with an unknown or incomplete genome [57-59]. Comparative genomic and proteomic studies have demonstrated that the amino acid sequence of proteins is significantly conserved across species boundaries. The conserved nature of many biosynthetic, metabolic, and regulatory pathways in different organisms was the basis for earlier studies of cross-species protein identification for species whose genome sequence were unknown or incomplete. Molecular information on cell wall biogenesis and dynamics of dinoflagellates is totally lacking due to the lack of a dinoflagellate genome at the present. For example, not a single CWP has been identified from dinoflagellates. In this study, approximately two thirds of the tested protein spots failed to be characterized in the protein databases, which might be caused by the low sequence homology matching for unambiguous protein identification across species boundaries. Studies have shown that amino acid residue substitutions occur in many positions of a specific protein across species boundaries resulting from evolutionary divergence as well as numerous posttranslational modifications, for example, phosphorylation, glycosylation, and acetylation, which might reduce or diminish the probability or efficiency of cross-species identification. In addition, low abundance and limited number of CWP sequences present in the available databases might further contribute to the limitations of the technique.

In summary, our study provided a newly developed method for identifying and characterizing CWPs from $A$. catenella. By combining the sequential extraction method for CWPs and the protoplast preparation method, the CWPs were separated from cytosolic proteins using the 2D DIGE method. This method has the potential to become a reliable complement to other methods currently used in studies of dinoflagellate CWPs. As a preliminary study, 120 CWPs were recognized, and 42 were characterized, such as cell wall-modifying enzymes, cell wall structural proteins, transport/binding proteins, signaling, and defense proteins. More insights can be expected; for example, the rapid analysis of many CWPs as well as the characterization of the proteomic changes occurring at the cell wall in response to environmental stresses are expected to facilitate the identification of new surface-exposed targets, and this can certainly improve our understanding of the relationship between cells and environmental variations.

\section{Acknowledgments}

This work was partially supported by research grants from the Specialized Research Fund for the Doctoral Program of Higher Education (no. 20070384014), the National Natural Science Foundation of China (nos. 40776068 and 40876059), the Ministry of Science and Technology of the People's Republic of China (Project no. 2010CB428703), the Excellent Group and the Program for New Century Excellent Talents in University to D.-Z. Wang. Professor John Hodgkiss is thanked for his help in polishing the English in this paper.

\section{References}

[1] F. J. R. Taylor, The Biology of Dinoflagellates, Black Well Scientific Publications, Oxford, UK, 1987.

[2] M. Kodama, "Ecobiology, classification, and origin," in Seafood and Freshwater Toxins: Pharmacology, Physiology and Detection, L. M. Botana, Ed., pp. 125-151, Marcel Dekker, New York, NY, USA, 2000.

[3] G. M. Hallegraeff, "Harmful algal blooms: a global overview," in Manual on Harmful Marine Microalgae, G. M. Hallegraeff, D. M. Anderson, and A. D. Cembella, Eds., pp. 25-49, Imprimerie Landais, Paris, France, 2005.

[4] D. M. Anderson, A. D. Cembella, and G. M. Hallegraeff, Physiological Ecology of Harmful Blooms, Springer, Berlin Heidelberg, Germany, 1998.

[5] A. R. Loeblich, "The amphiesma or dinoflagellate cell covering," in Proceedings of the North American Paleont. Convention, Chicago, pp. 867-929, Allen Press, Lawrence, Kan, USA, 1969.

[6] A. R. Loeblich and L. A. Loeblich, "Dinoflagellates: structure of the amphiesma and re-analysis of thecal plate patterns," Hydrobiologia, vol. 123, no. 2, pp. 177-179, 1985.

[7] D. J. Scanlan, N. H. Mann, and N. G. Carr, "The response of the picoplanktonic marine cyanobacterium Synechococcus species WH7803 to phosphate starvation involves a protein homologous to the periplasmic phosphate-binding protein of Escherichia coli," Molecular Microbiology, vol. 10, no. 1, pp. 181-191, 1993.

[8] B. Song and B. B. Ward, "Molecular cloning and characterization of high-affinity nitrate transporters in marine phytoplankton," Journal of Phycology, vol. 43, no. 3, pp. 542552, 2007.

[9] Y. Tamai, A. Toh-e, and Y. Oshima, "Regulation of inorganic phosphate transport systems in Saccharomyces cerevisiae," Journal of Bacteriology, vol. 164, no. 2, pp. 964-968, 1985. 
[10] H. M. ElBerry, M. L. Majumdar, T. S. Cunningham, R. A. Sumrada, and T. G. Cooper, "Regulation of the urea active transporter gene (DUR3) in Saccharomyces cerevisiae," Journal of Bacteriology, vol. 175, no. 15, pp. 4688-4698, 1993.

[11] M. T. Maldonado and N. M. Price, "Reduction and transport of organically bound iron by Thalassiosira oceanica (Bacillariophyceae)," Journal of Phycology, vol. 37, no. 2, pp. 298-309, 2001.

[12] C. C. Chung, S. P. Hwang, and J. Chang, "Identification of a high-affinity phosphate transporter gene in a Prasinophyte alga, Tetraselmis chui, and its expression under nutrient limitation," Applied and Environmental Microbiology, vol. 69, no. 2, pp. 754-759, 2003.

[13] M. Hildebrand, "Cloning and functional characterization of ammonium transporters from the marine diatom Cylindrotheca fusiformis (Bacillariophyceae)," Journal of Phycology, vol. 41, no. 1, pp. 105-113, 2005.

[14] A. E. Allen, "Beyond sequence homology: redundant ammonium transporters in a marine diatom are not functionally equivalent," Journal of Phycology, vol. 41, no. 1, pp. 4-6, 2005.

[15] A. K. Davis, M. Hildebrand, and B. Palenik, "A stressinduced protein associated with the girdle band region of the diatom Thalassiosira pseudonana (Bacillariophyta)," Journal of Phycology, vol. 41, no. 3, pp. 577-589, 2005.

[16] C. M. West, P. Zhang, A. C. McGlynn, and L. Kaplan, "Outside-in signaling of cellulose synthesis by a spore coat protein in Dictyostelium," Eukaryotic Cell, vol. 1, no. 2, pp. 281-292, 2002.

[17] D. M. Landry, T. Gaasterland, and B. P. Palenik, "Molecular characterization of a phosphate-regulated cell-surface protein from the coccolithophorid, Emiliania huxleyi (Prymnesiophyceae)," Journal of Phycology, vol. 42, no. 4, pp. 814-821, 2006.

[18] B. Palenik and F. M. M. Morel, "Amino acid utilization by marine phytoplankton: a novel mechanism," Limnology and Oceanography, vol. 35, no. 2, pp. 260-269, 1990.

[19] B. Palenik and F. M. M. Morel, "Comparison of cell-surface L-amino acid oxidases from several marine phytoplankton," Marine Ecology Progress Series, vol. 29, pp. 195-201, 1990.

[20] B. Palenik and F. M. M. Morel, "Amine oxidases of marine phytoplankton," Applied and Environmental Microbiology, vol. 57, no. 8, pp. 2440-2443, 1991.

[21] A. Strojsova, J. Vrba, J. Nedoma, and K. Simek, "Extracellular phosphatase activity of freshwater phytoplankton exposed to different in situ phosphorus concentrations," Marine and Freshwater Research, vol. 56, no. 4, pp. 417-424, 2005.

[22] S. T. Dyhrman and B. Palenik, "Characterization of ectoenzyme activity and phosphate-regulated proteins in the coccolithophorid Emiliania huxleyi," Journal of Plankton Research, vol. 25, no. 10, pp. 1215-1225, 2003.

[23] J. K. Middlemiss, A. M. Anderson, C. W. Stratilo, and H. G. Weger, "Oxygen consumption associated with ferric reductase activity and iron uptake by iron-limited cells of Chlorella kessleri (Chlorophyceae)," Journal of Phycology, vol. 37, no. 3, pp. 393-399, 2001.

[24] Y. Xu, T. M. Wahlund, L. Feng, Y. Shaked, and F. M. M. Morel, "A novel alkaline phosphatase in the coccolithophore Emiliania huxleyi (Prymnesiophyceae) and its regulation by phosphorus," Journal of Phycology, vol. 42, no. 4, pp. 835-844, 2006.

[25] A. E. Gau, A. Heindl, A. Nodop, U. Kahmann, and E. K. Pistorius, "L-amino acid oxidases with specificity for basic Lamino acids in cyanobacteria," Journal of Biosciences, vol. 62, no. 3-4, pp. 273-284, 2007.
[26] B. Palenik and J. A. Koke, "Characterization of a nitrogenregulated protein identified by cell surface biotinylation of a marine phytoplankton," Applied and Environmental Microbiology, vol. 61, no. 9, pp. 3311-3315, 1995.

[27] S. T. Dyhrman and B. Palenik, "The identification and purification of a cell-surface alkaline phosphatase from the dinoflagellate Prorocentrum minimum (Dinophyceae)," Journal of Phycology, vol. 33, no. 4, pp. 602-612, 1997.

[28] D. K. Stoecker and D. E. Gustafson, "Cell-surface proteolytic activity of photosynthetic dinoflagellates," Aquatic Microbial Ecology, vol. 30, no. 2, pp. 175-183, 2003.

[29] S. T. Dyhrman, "Ectoenzymes in Prorocentrum minimum," Harmful Algae, vol. 4, no. 3, pp. 619-627, 2005.

[30] T. Bertomeu, J. W. Hastings, and D. Morse, "Vectorial labeling of dinoflagellate cell surface proteins," Journal of Phycology, vol. 39, no. 6, pp. 1254-1260, 2003.

[31] D. Robertson, G. P. Mitchell, J. S. Gilroy, C. Gerrish, G. P. Bolwell, and A. R. Slabas, "Differential extraction and protein sequencing reveals major differences in patterns of primary cell wall proteins from plants," Journal of Biological Chemistry, vol. 272, no. 25, pp. 15841-15848, 1997.

[32] S. B. Wang, Q. Hu, M. Sommerfeld, and F. Chen, "Cell wall proteomics of the green alga Haematococcus pluvialis (Chlorophyceae)," Proteomics, vol. 4, no. 3, pp. 692-708, 2004.

[33] F. Huang, E. Hedman, C. Funk, T. Kieselbach, W. P. Schroder, and B. Norling, "Isolation of outer membrane of Synechocystis sp. PCC 6803 and its proteomic characterization," Molecular and Cellular Proteomics, vol. 3, no. 6, pp. 586-595, 2004.

[34] L. L. Chan, S. C. L. Lo, and I. J. Hodgkiss, "Proteomic study of a model causative agent of harmful red tide, Prorocentrum triestinum I: optimization of sample preparation methodologies for analyzing with two-dimensional electrophoresis," Proteomics, vol. 2, no. 9, pp. 1169-1186, 2002.

[35] L. L. Chan, I. J. Hodgkiss, and S. C. L. Lo, "Proteomic study of a model causative agent of harmful algal blooms, Prorocentrum triestinum II: the use of differentially expressed protein profiles under different growth phases and growth conditions for bloom prediction," Proteomics, vol. 4, no. 10, pp. 3214-3226, 2004.

[36] L. L. Chan, I. J. Hodgkiss, S. H. Lu, and S. C. L. Lo, "Use of 2DE electrophoresis proteome reference maps of dinoflagellates for species recognition of causative agents of harmful algal blooms," Proteomics, vol. 4, no. 1, pp. 180-192, 2004.

[37] L. L. Chan, I. J. Hodgkiss, P. K. Lam et al., "Use of twodimensional gel electrophoresis to differentiate morphospecies of Alexandrium minutum, a paralytic shellfish poisoning toxin-producing dinoflagellate of harmful algal blooms," Proteomics, vol. 5, no. 6, pp. 1580-1593, 2005.

[38] L. L. Chan, W. H. Sit, P. K. S. Lam et al., "Identification and characterization of a "biomarker of toxicity" from the proteome of the paralytic shellfish toxin-producing dinoflagellate Alexandrium tamarense (Dinophyceae)," Proteomics, vol. 6, no. 2, pp. 654-666, 2006.

[39] N. B. Larbi and C. Jefferies, "2D-DIGE: comparative proteomics of cellular signalling pathways," Methods in Molecular Biology, vol. 517, pp. 105-132, 2009.

[40] H. L. Huang, T. Stasyk, S. Morandell et al., "Biomarker discovery in breast cancer serum using 2-D differential gel electrophoresis/MALDI-TOF/TOF and data validation by routine clinical assays," Electrophoresis, vol. 27, no. 8, pp. 16411650, 2006.

[41] Y. Fan, T. B. Murphy, J. C. Byrne, L. Brennan, J. M. Fitzpatrick, and R. W. G. Watson, "Applying random forests to identify 
biomarker panels in serum 2D-DIGE data for the detection and staging of prostate cancer," Journal of Proteome Research, vol. 10, no. 3, pp. 1361-1373, 2011.

[42] T. Kondo, "Tissue proteomics for cancer biomarker development-laser microdissection and 2D-DIGE," Journal of Biochemistry and Molecular Biology Reports, vol. 41, no. 9, pp. 626-634, 2008.

[43] R. Kramer and D. Cohen, "Functional genomics to new drug targets," Nature Reviews Drug Discovery, vol. 3, no. 11, pp. 965-972, 2004.

[44] D. Z. Wang, S. G. Zhang, H. F. Gu, L. L. Chan, and H. S. Hong, "Paralytic shellfish toxin profiles and toxin variability of the genus Alexandrium (Dinophyceae) isolated from the Southeast China Sea," Toxicon, vol. 48, no. 2, pp. 138-151, 2006.

[45] M. D. Keller, R. C. Selvin, W. Claus, and R. R. L. Guillard, "Media for the culture of oceanic ultraphytoplankton," Journal of Phycology, vol. 23, pp. 633-638, 1987.

[46] D. Z. Wang, C. Li, Z. X. Xie, P. D. Dong, L. Lin, and H. S. Hong, "Homology-driven proteomics of dinoflagellates with unsequenced genome by MALDI-TOF/TOF and automated de novo sequencing," eCAM. In press.

[47] D. J. Cosgrove, "Enzymes and other agents that enhance cell wall extensibility," Annual Review of Plant Biology, vol. 50, pp. 391-417, 1999.

[48] S. C. Fry, "Polysaccharide-modifying enzymes in the plant cell wall," Annual Review of Plant Physiology and Plant Molecular Biology, vol. 46, pp. 497-520, 1995.

[49] J. J. Gumucio and J. D. Ostrow, "Brown pigment gallstones: the role of bacterial hydrolases and another missed opportunity," Hepatology, vol. 13, no. 3, pp. 607-609, 1991.

[50] Z. Minic, "Physiological roles of plant glycoside hydrolases," Planta, vol. 227, no. 4, pp. 723-740, 2008.

[51] S. H. Kim, J. R. Shinkle, and S. J. Roux, "Phytochrome induces changes in the immunodetectable level of a wall peroxidase that precede growth changes in maize seedlings," Proceedings of the National Academy of Sciences of the United States of America, vol. 86, no. 24, pp. 9866-9870, 1989.

[52] W. Z. Liu, Y. Hu, R. J. Zhang et al., "Transfer of a eubacteriatype cell division site-determining factor CrMinD gene to the nucleus from the chloroplast genome in Chlamydomonas reinhardtii," Chinese Science Bulletin, vol. 52, no. 18, pp. 25142521, 2007.

[53] B. D. Kohorn, "Plasma membrane-cell wall contacts," Plant Physiology, vol. 124, no. 1, pp. 31-38, 2000.

[54] O. C. Silva, "CG-1, a parsley light-induced DNA-binding protein," Plant Molecular Biology, vol. 25, no. 5, pp. 921-924, 1994.

[55] J. Grimwood, L. Olinger, and R. S. Stephens, "Expression of Chlamydia pneumoniae polymorphic membrane protein family genes," Infection and Immunity, vol. 69, no. 4, pp. 23832389, 2001.

[56] F. Volpe, M. Dyer, J. G. Scaife, G. Darby, D. K. Stammers, and C. J. Delves, "The multifunctional folic acid synthesis fas gene of Pneumocystis carinii appears to encode dihydropteroate synthase and hydroxymethyldihydropterin pyrophosphokinase," Gene, vol. 112, no. 2, pp. 213-218, 1992.

[57] A. L. Yergey, J. R. Coorssen, P. S. Backlund et al., "De novo sequencing of peptides using MALDI/TOF-TOF," Journal of the American Society for Mass Spectrometry, vol. 13, no. 7, pp. 784-791, 2002.
[58] N. S. Tannu and S. E. Hemby, "De novo protein sequence analysis of Macaca mulatta," BMC Genomics, vol. 8, article 270, 2007.

[59] B. Samyn, K. Sergeant, S. Memmi, G. Debyser, B. Devreese, and J. Van Beeumen, "MALDI-TOF/TOF de novo sequence analysis of 2-D PAGE-separated proteins from Halorhodospira halophila, a bacterium with unsequenced genome," Electrophoresis, vol. 27, no. 13, pp. 2702-2711, 2006. 


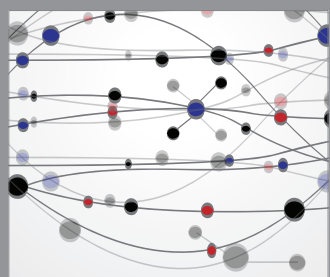

The Scientific World Journal
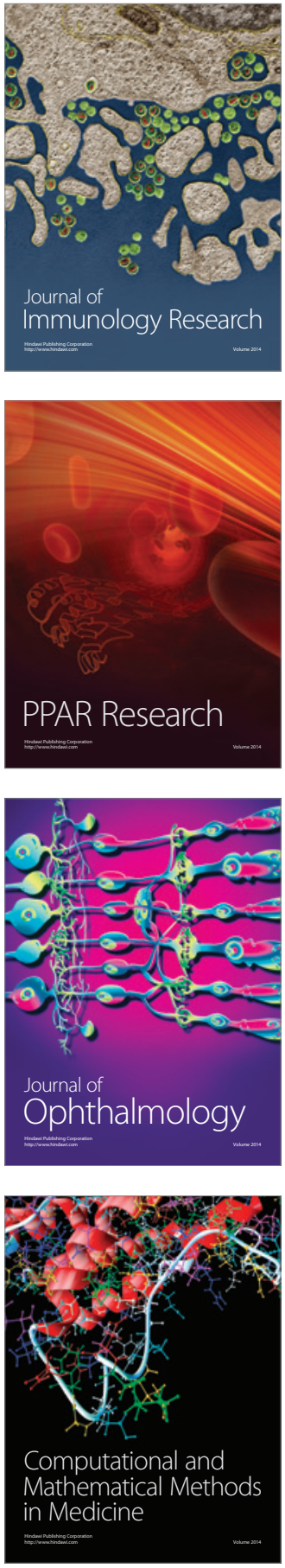

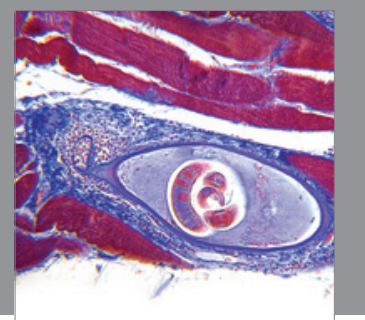

Gastroenterology

Research and Practice
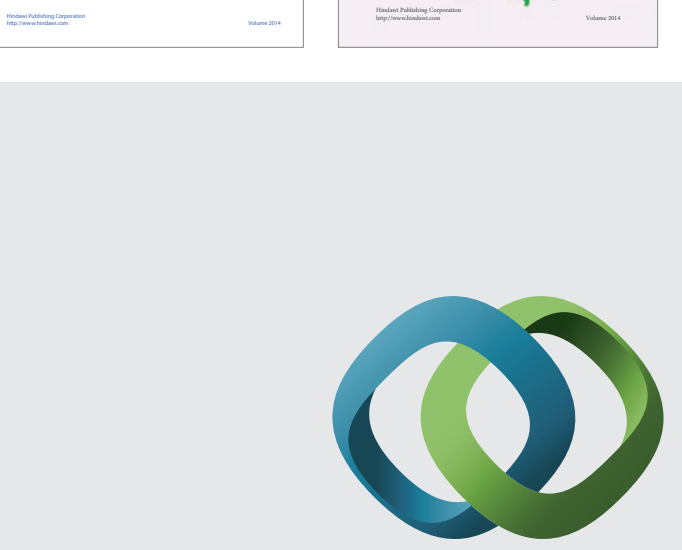

\section{Hindawi}

Submit your manuscripts at

http://www.hindawi.com
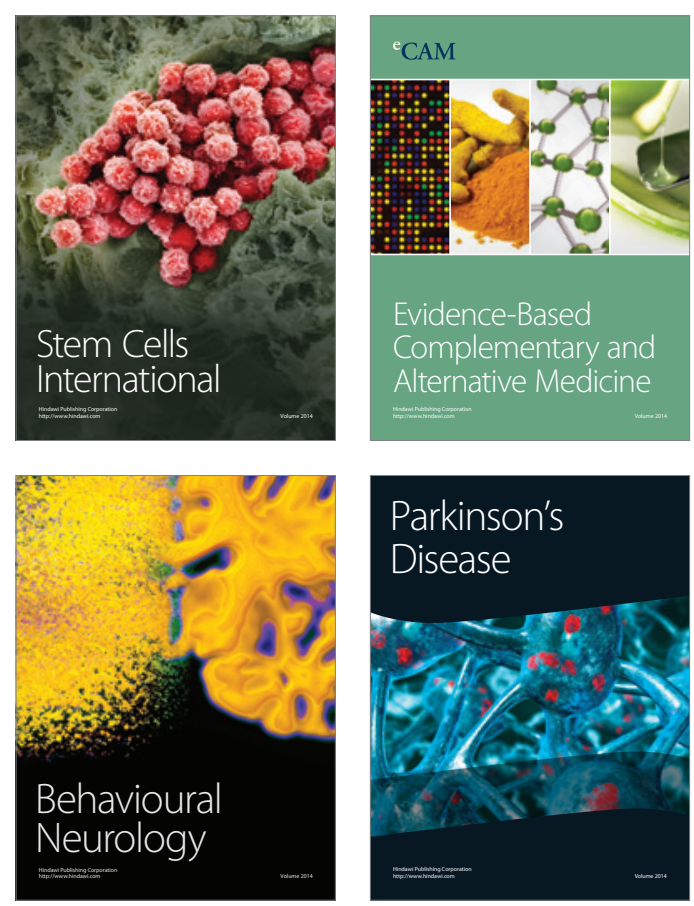

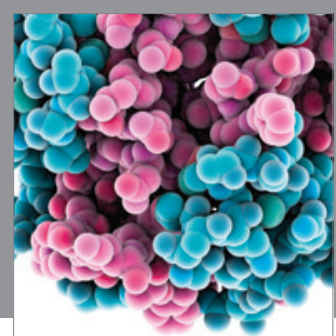

Journal of
Diabetes Research

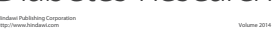

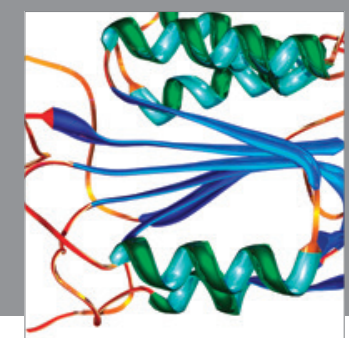

Disease Markers
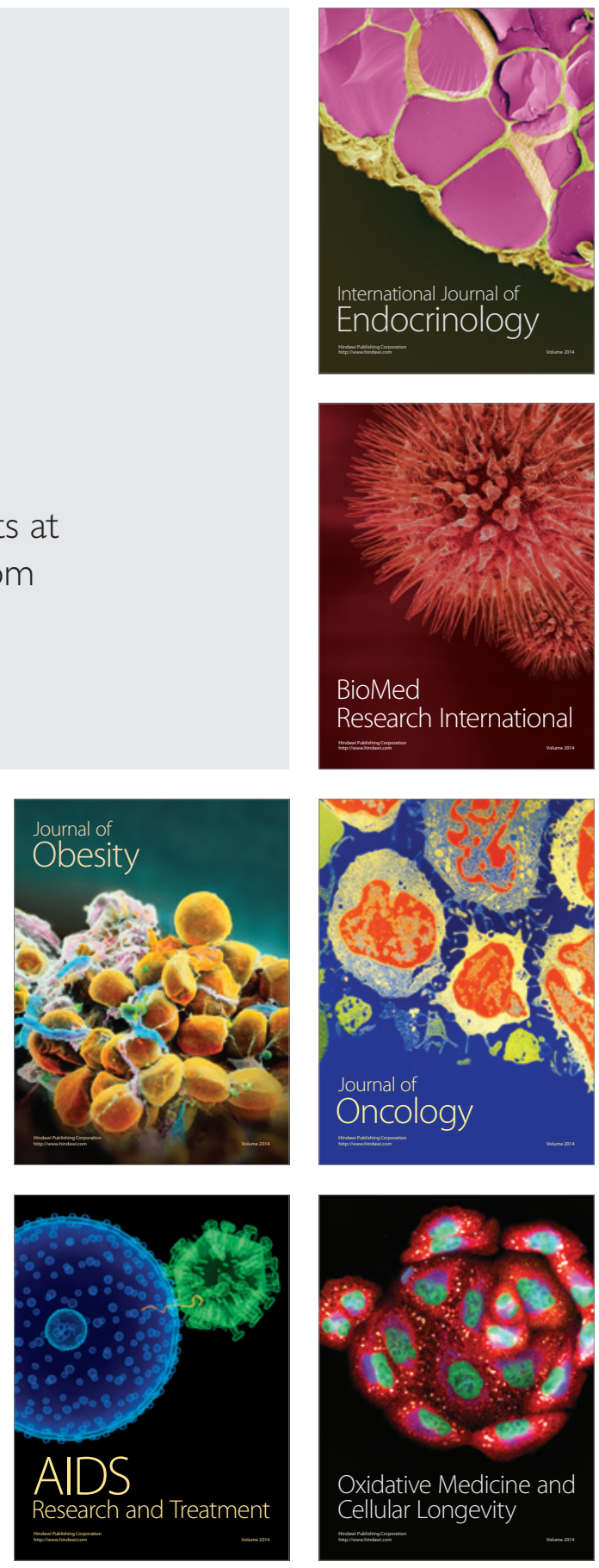